\title{
A new species of Lucasium (Squamata: Diplodactylidae) from the southern deserts of Western Australia and South Australia
}

\author{
Paul Doughty ${ }^{1}$ and Mark N. Hutchinson ${ }^{2}$ \\ 'Department of Terrestrial Zoology, Western Australian Museum, 49 Kew Street, Welshpool, \\ Western Australia 6106, Australia. E-mail: Paul.Doughtyamuseum.wa.gov.au \\ South Australian Museum, North Terrace, Adelaide, South Australia 5000, Australia, and \\ School of Earth and Environmental Sciences, University of Adelaide, Adelaide, \\ South Australia 5005, Australia. E-mail: hutchinson markosaugov. sa.gov.au
}

\begin{abstract}
Discoveries of new species of Australian squamates continue following explorations of remote regions, examination of large series of taxa that differ subtly and through genetic techniques. Here we describe a new species of Lucasium from the southern deserts of Western Australia and South Australia. Lucasium bungabinna sp. nov, differs from congeners by possessing relatively wide apical plates, a simple body pattern consisting of a pale vertebral stripe and lateral spotting, slightly more robust body and tail and nostril in contact with rostral scale. The new taxon occurs on the Bungalbin sandplain in Westem Australia and the Yellabinna Sandplain in South Australia, extending to the Eyre Peninsula.
\end{abstract}

\section{INTRODUCTION}

The Australian arid zone boasts the most diverse desert lizard fauna in the world (Pianka 1989). Local faunal assemblages can include 50 or more species, and the total number of species currently known to inhabit desert and semidesert habitats (mean annual rainfall $<200 \mathrm{~mm}$ ) is at least 270 (based on range maps in Wilson and Swan 2003). Even so, these numbers are an underestimate of the true diversity. Many of Australia's widespread lizard genera and species are likely to harbour as yet undescribed species (Donnellan et al. 1993), and many of the more successful lizard lineages in desert areas have still to be fully investigated for cryptic species. Such cryptic species can be detected by examining large series of preserved museum specimens in combination with genetic screens across large areas of the arid zone.

The Australian diplodactylid genus Lucasium Wermuth 1965 is a group of small, terrestrial, desert-dwelling geckos, until recently mostly included in Diplodactylus Gray, 1832 (Baver et al. 1988; Storr et al. 1990; Cogger 2000; Wilson and Swan 2003; Oliver et al. 2007). The species diversity in this genus (as the Diplodactylus stenodactylus species-group) was recently examined by Pepper et al. (2006), who showed that there was significant divergence in mitochondrial gene sequences among specimens identified phenotypically as $L$. stenodactylum (Boulenger, 1896). In both this and the later paper by Oliver et al. (2007), the "species" $L$. stenodactylum was regarded as probably encompassing several species.
Kluge (1967) long ago suggested that there was significant morphological variation in $L$. stenodactylum. His "Population A" from Western Australia comprised specimens from the western deserts, including the type locality of $L$. stenodactylum (Roebuck Bay off Broome), and includes specimens having numerous large and small lateral spots, and with variable expression of a pale vertebral stripe that forks on the neck to end over each eye. These animals have small but still distinct and possibly functional apical plates (or scansors), and a reduced phalangeal formula in the fourth finger (four instead of five phalanges). Kluge's "Population B" from central Australia (including a large series from Warburton) had a more distinct colour pattern, with fewer, sharpedged lateral spots and the consistent presence of a strongly defined pale vertebral stripe. This form had variable (small to vestigial) apical plates and variable phalangeal counts in the fourth finger (four in the north, five in the south with both counts recorded in central Australia). Pepper et al. (2006) showed that the variation within L. stenodactylum is more complex than Kluge's simple dichotomy, with at least three species probably present within Kluge's Population B forms (designated "nonPilbara", "Species 1" and "Species 2").

Species 2 specimens from the southern deserts of Western Australia and South Australia are distributed south of the geographic range of $L$. stenodactylum of either of Kluge's forms (Kluge 1967, fig. 10; Storr et al. 1990, figure p. 41; Figure 1). Molecular phylogenetic work also shows that 


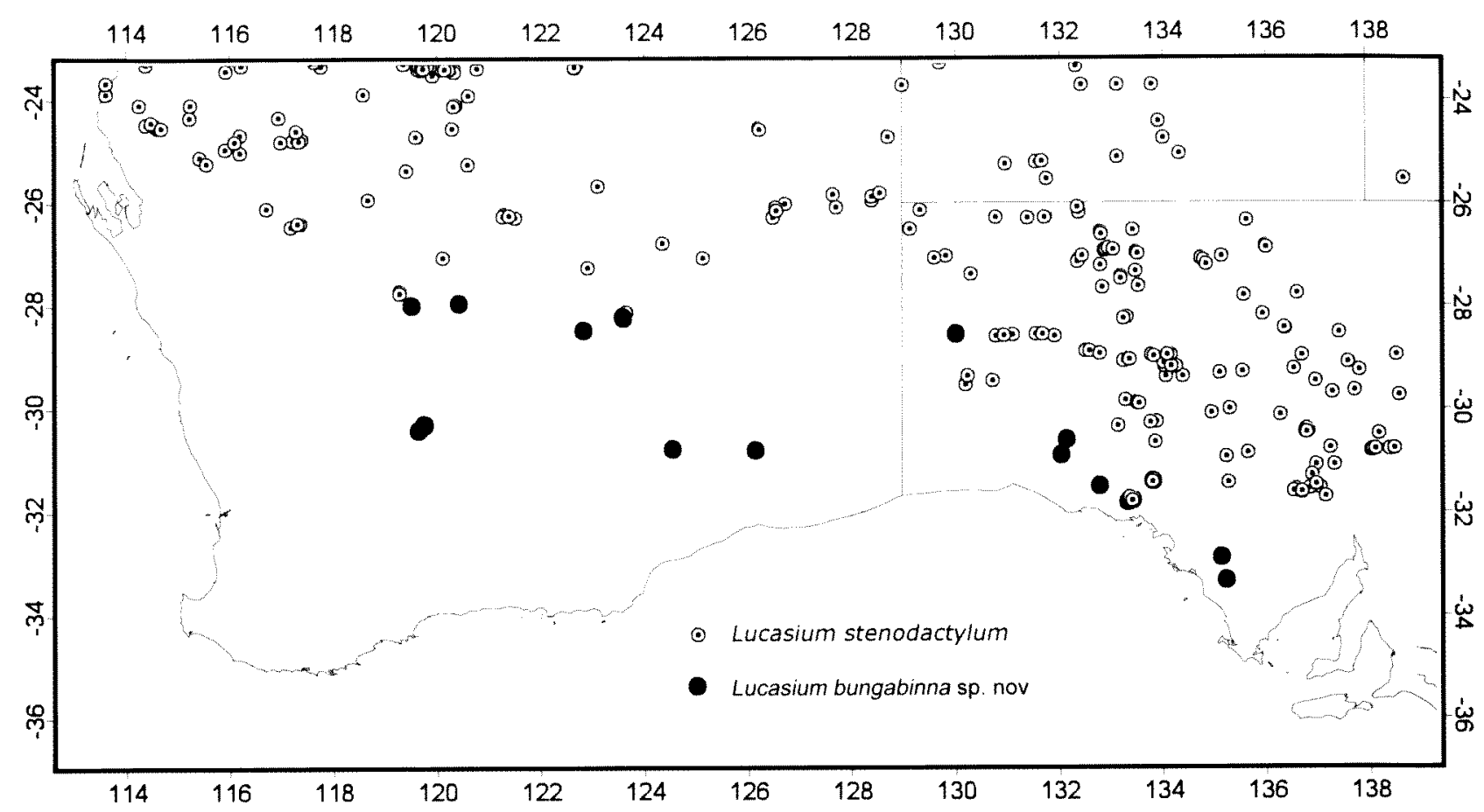

Figure 1 Distribution of Lucasium bungabinna sp. nov. and L. stenodactylum in southern Australia.

Species 2 is not closely related to other populations currently included in L. stenodactylum (Pepper et al. 2006), but is instead closely related to another species of Lucasium, L. immaculatum (Storr, 1988) from western Queensland and eastern Northern Territory (Oliver et al. 2007). Unpublished allozyme results (S. Donnellan and $\mathrm{M}$. Adams), also indicate that Species 2 is distinct from $L$. stenodactylum. These Lucasium populations have much larger terminal apical plates than any other population included under L. stenodactylum, and differ subtly in colour and pattern. A revision of $L$. stenodactylum is in preparation (P. Doughty, M. Pepper and J. S. Keogh, unpublished data), but the distinctiveness of Species 2 has enabled us to describe it herein as a new species.

\section{MATERIALS AND METHODS}

Specimens in the collections of the Western Australian Museum, Perth (WAM) and the South Australian Museum, Adelaide (SAMA) form the basis of this description. All specimens used in the molecular studies (allozymes or DNA sequences) were examined morphologically. Well-preserved specimens that conformed to the set of character states defined by these typed specimens and were from the same area were regarded as conspecific. Osteological characters of the skull were examined in two dry specimens prepared using bleachassisted hand dissection. Phalangeal counts of the fourth finger were checked by peeling away the skin of the left fourth finger in several individuals. Specimens of the new species that are not the
Table 1 Meristic characters and their abbreviations used in this study.

\begin{tabular}{|c|c|}
\hline SVL & Snout-vent length \\
\hline TrunkL & Trunk length from axilla to groin \\
\hline TL & Tail length of original tails \\
\hline TailW & Tail width at widest point on original tails \\
\hline ArmL & Foreleg length from elbow to tip of $4^{\text {th }}$ finger \\
\hline LegL & $\begin{array}{l}\text { Tibia length from upper surface of knee to } \\
\text { tip of } 4^{\text {th }} \text { toe }\end{array}$ \\
\hline HeadL & $\begin{array}{l}\text { Head length from tip of snout to } \\
\text { retroarticular process }\end{array}$ \\
\hline HeadW & Head width at widest point \\
\hline HeadH & Head height at highest point \\
\hline OrbL & $\begin{array}{l}\text { Orbit length from lower anterior to upper } \\
\text { posterior comers }\end{array}$ \\
\hline NarEye & Distance from naris to anterior corner of eye \\
\hline SnEye & Distance from snout to anterior corner of eye \\
\hline EyeEar & $\begin{array}{l}\text { Distance from posterior edge of eye to } \\
\text { anterior margin of ear }\end{array}$ \\
\hline INar & Internarial distance \\
\hline $\mathrm{IO}$ & Interorbital width at centre of eyes \\
\hline SupLab & Number of supralabial scales \\
\hline InfLab & Number of infralabial scales \\
\hline CreaseL & $\begin{array}{l}\text { Proportional length of the crease on rostral } \\
\text { scale }\end{array}$ \\
\hline IntNar & $\begin{array}{l}\text { Presence or absence of minute internarial } \\
\text { scale }\end{array}$ \\
\hline AntSup & Number of anterior supranasals \\
\hline PostNas & Number of postnasal scales \\
\hline NolO & Number of scales between centre of orbits \\
\hline NoSC & $\begin{array}{l}\text { Number of subcaudal scales from fracture } \\
\text { plane to tip on original tails }\end{array}$ \\
\hline Rella & Relative height of $1^{\text {th }}$ and $2^{\text {nd }}$ labial scales \\
\hline & Average number of enlarged cloacal spurs \\
\hline Cspurs-T & $\begin{array}{l}\text { Average total number of clocal spurs (small } \\
\text { and large) }\end{array}$ \\
\hline MenL/W & Ratio of length/width of mental scale \\
\hline
\end{tabular}


holotype or paratypes as well as specimens of $L$ stenodactylum from the adjoining regions to the north in each state are given in the Appendix.

Table 1 defines the meristic characters, and their abbreviations, used in this study. These measurements and scale counts are presented in Table 2 for 42 specimens of Species 2 and 25 specimens of the nearest populations of $L$. stenodactylum from Western Australian and South Australia. We also calculated the following ratios: TrunkL/SVL, ArmL/SVL, LegL/SVL, HeadL/SVL, HeadW/SVL, HeadH/SVL and TailL\%SVL. Examination of the raw data indicated no violations of assumptions of parametric tests; therefore, tests were carried out on untransformed data. We tested whether there were differences in SVL according to sex and taxon with a 2-way ANOVA. For the following variables, we used 2-way ANCOVAs to test for sex and taxon, using SVL as a covariate: TrunkL, TailL, ArmL, LegL, HeadL, HeadW, HeadH, NolO and NoSC. For all statistical tests, interaction and covariates were deleted from models when $P>0.05$.

\section{Taxonomy}

\section{Family Diplodactylidae Underwood 1954}

\section{Lucasium Wermuth 1965}

Lucasium Wermuth 1965: x, 100.

\section{Type species}

Lucasium damaeum Wermuth 1965, by monotypy.

\section{Remarks}

We follow the expanded concept of Lucasium outlined in Oliver et al. (2007) as a genus of the Diplodactylidae (sensu Han et al. 2004) distinguished from all Australian diplodactylids but Diplodactylus and Rhynchoedura by having both lateral and medial pairs of cloacal bones present. Distinguished from Diplodactylus and Rhynchoedura Güther, 1867 by the reduced or vestigial jugal and medial expansion of the suborbital portion of the maxilla. Further distinguished from Diplodactylus by low numbers of preanal spinose scales (generally 2-5), presence of preanal pores (usually one left and one right) in males (absent in L. maini [Kluge, 1962a]) and by more gracile, elongate proportions of the body, limbs and tail; fourth toe of hind foot approximately seven times as long as wide, tail narrow and moderate to long $(80 \%$ to $110 \%$ of SVL). Further distinguished from Rhynchoedura by lower presacral vertebral count (mode 26 versus mode 27), more robust skull, absence of beak-like projecting mental and rostral scales and absence of enlarged preanal pore scales (Greer
1989). The new species shares all of the diagnostic features of the genus.

\section{Lucasium bungabinna sp. nov. Southern Sandplain Gecko} Figures 2-4

"Diplodactylus species 2": Pepper et al. 2006: 542

"Diplodactylus stenodactylus": Bush et al. 2007: 115

\section{Material examined}

\section{Holotype}

Australia: Western Australia: WAM R166888. An adult male from $16 \mathrm{~km}$ northeast of Bungalbin Hill at $30^{\circ} 17^{\prime} 40^{\prime \prime} \mathrm{S}, 119^{\circ} 44^{\prime} 50^{\prime \prime} \mathrm{E}$. Collected by D. Robinson on 7 April 2007.

\section{Paratypes}

Australia: Western Australia: (all in WAM): R121955 (M) and R121956 (M) - Bungalbin Hill, $30^{\circ} 42^{\prime} \mathrm{S}, 119^{\circ} 38^{\prime} \mathrm{E}$; R126400 (M), R126405 (M) Bungalbin Sandplain, $30^{\circ} 17^{\prime} \mathrm{S}, 119^{\circ} 45^{\prime} \mathrm{E}$; R 151202

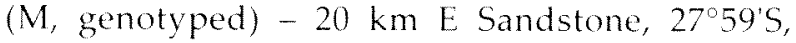
$119^{\circ} 30^{\prime} \mathrm{E}$; R147385 (F), R155409 (F), R155410 (F) and R155412 (F) - 7-8 km WNW Point Salvation, $28^{\circ} 12^{\prime} \mathrm{S}, 123^{\circ} 35^{\prime} \mathrm{E}$; R155413 (M) and R155417 (M) $7-8 \mathrm{~km}$ WNW Point Salvation, 28 14'S, $123^{\circ} 36^{\prime} \mathrm{E}$.

Australia: South Australia: (all in SAMA): R56597(M) - Ketchalby Rock Hole, 32³9'31"S, 134 59'28'E; R59368 (M) - 22.5 km NW Maralinga, $30^{\circ} 01^{\prime} 16^{\prime \prime} \mathrm{S}, 131^{\circ} 24^{\prime} 32^{\prime \prime} \mathrm{E}$; R59774 (M) - $2.9 \mathrm{~km} \mathrm{NE}$ of

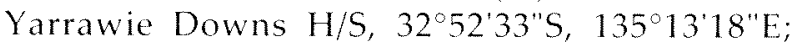
R60342 (F) - 152 km W Oak Valley, 29 32'28"S, 129006'16"E; R61197 (F) - 6 km SE Pidinga Tank, Lake Ifould, $30^{\circ} 53^{\prime} 43^{\prime \prime} \mathrm{S}, 132^{\circ} 10^{\prime} 01^{\prime \prime} \mathrm{E}$; R61310 (M) $8.2 \mathrm{~km}$ NNW Oak Hill, 32008'31'S, 134 20'36"E; R61443 (F) - 9 km NNW Uwarra, $31^{\circ} 53^{\prime} 08^{\prime \prime} S$, $133^{\circ} 18^{\prime} 25^{\prime \prime} \mathrm{E}$; R62250 (M) - adj Anne Beadell Hwy at Serpentine Lakes, $28^{\circ} 20^{\prime} 25^{\prime \prime} \mathrm{S}, 1^{\circ} 9^{\circ} 00^{\prime} 50^{\prime \prime} \mathrm{E}$; R62265 (F) - adj Anne Beadell Hwy at Serpentine Lakes, 28 29'57'S, 129 02'29"E; R62338 (F) - Anne Beadell Hwy, $47 \mathrm{~km} \mathrm{~W}$ Vokes Hill comer, 28 $32^{\prime} 22^{\prime \prime} \mathrm{S}$, $130^{\circ} 08^{\prime} 53^{\prime \prime} \mathrm{E}$

\section{Diagnosis}

A moderately large Lucasium distinguished from other members of the genus by the unique combination of its relatively large apical plates (apical plate pair slightly wider than finger; apical plate length more than twice that of claw in ventral view; Figure $2 \mathrm{~B}$ ); rostral bordering the nostril, separating anterior supranasal from first supralabial (Figure 2A); consistent presence of a well-defined vertebral stripe (Figures 3 and 4); relatively simple pattern of lateral spotting; digit undersides with a median series of enlarged, mostly single, subdigital scales (Figure 2B). 
Table 2 Summaries of characters and ratios measured for Lucasium stenodactylum and L. bungabinna sp. nov. Mean \pm S.D. (range). Sample sizes are listed in column headings, unless noted for individual characters below. See Table 1 for abbreviations. SVL was tested with a 2-way ANOVA. 2-way ANCOVAs (factors - species and sex, covariate - SVL) were carried out (see text for explanation) and reported in the last column. All species X sex interaction terms were not significant with alpha $=0.05$. Key: NS - not significant: $\mathrm{P}>0.05,{ }^{*} \mathrm{P}<0.05,{ }^{* *} \mathrm{P}$ $<0.01,{ }^{* * *} \mathrm{P}<0.001,{ }^{* * * *} \mathrm{P}<0.0001$.

\begin{tabular}{|c|c|c|c|}
\hline Character & $\begin{array}{l}\text { L. stenodactylum } \\
\mathrm{N}=42\end{array}$ & $\begin{array}{l}\text { L. bungabinna sp. nov. } \\
\qquad \mathrm{N}=\mathbf{2 5}\end{array}$ & Statistics \\
\hline SVL & $\begin{array}{c}\text { Female }(\mathrm{N}=12) \text { : } \\
54.5 \pm 5.8 \\
(41.0-62.5) \\
\text { Males }(\mathrm{N}=30): \\
51.0 \pm 3.9 \\
(45.0-59.5)\end{array}$ & $\begin{array}{c}\text { Female }(\mathrm{N}=11) \\
51.5 \pm 2.6 \\
(47.0-56.0) \\
\text { Males }(\mathrm{N}=14) \\
49.0 \pm 4.7 \\
(40.0-58.0)\end{array}$ & $\begin{array}{l}\text { Spp. }-F_{1,64}=4.500^{\circ} \\
\text { Sex }-F_{1,64}=7.461^{*}\end{array}$ \\
\hline TrunkL & 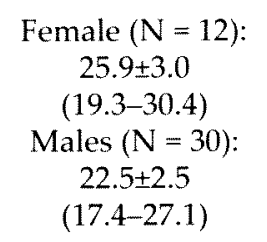 & $\begin{array}{l}\text { Female }(\mathrm{N}=11) \\
\begin{array}{c}24.0 \pm 1.9 \\
(20.7-27.0) \\
\text { Males }(\mathrm{N}=14) \\
22.0 \pm 2.8 \\
(18.0-25.9)\end{array}\end{array}$ & $\begin{array}{c}\text { Spp. }-F_{1,63}=0.395^{N S} \\
\text { Sex }-F_{1,63}=11.027^{*} \\
\text { SVL }-F_{1,63}=183.492^{* n * *}\end{array}$ \\
\hline TailL & $\begin{array}{c}45.4 \pm 5.6 \\
(32.0-55.0) \\
N=22\end{array}$ & $\begin{array}{c}38.2 \pm 5.1 \\
(32-49) \\
N=19\end{array}$ & $\begin{aligned} \text { Spp. }-F_{1,37} & =12.526^{* * *} \\
S e x-F_{1,37} & =0.951^{N S} \\
S V L-F_{1,37} & =37.698^{* * *}\end{aligned}$ \\
\hline TailW & $\begin{array}{c}6.1 \pm 0.9 \\
(4.6-8.1) \\
N=22\end{array}$ & $\begin{array}{c}4.2 \pm 0.9 \\
(3.0-5.4) \\
N=20\end{array}$ & $\begin{aligned} \text { Spp. }-F_{1,38} & =44.201^{* * *+} \\
\text { Sex }-F_{1,38} & =0.858^{N S} \\
S V L-F_{1,38} & =36.017^{* * *}\end{aligned}$ \\
\hline ArmL & $\begin{array}{c}11.6 \pm 1.0 \\
(8.5-13.3)\end{array}$ & $\begin{array}{c}10.6 \pm 0.9 \\
(8.1-12.0)\end{array}$ & $\begin{array}{c}\text { Spp. }-F_{1,63}=26.751^{* *+*} \\
\text { Sex }-F_{1,63}=0.559^{N S} \\
\text { SVL }-F_{1,6,3}=109.608^{* * * *}\end{array}$ \\
\hline LegL & $\begin{array}{c}15.4 \pm 1.3 \\
(11.0-18.2) \\
N=41\end{array}$ & $\begin{array}{c}14.0 \pm 1.0 \\
(11.0-15.5) \\
N=24\end{array}$ & $\begin{array}{c}\text { Spp. }-F_{1,61}=34.545^{+* 4} \\
\text { Sex }-F_{1,61}=0.066^{N S} \\
\text { SVL }-F_{1,61}=117.862^{* * * *}\end{array}$ \\
\hline HeadL & $\begin{array}{c}\text { Female }(\mathrm{N}=12) \text { : } \\
14.0 \pm 1.5 \\
(10.1-15.7) \\
\text { Males }(\mathrm{N}=29) \\
13.6 \pm 0.9 \\
(11.9-15.4)\end{array}$ & $\begin{array}{c}\text { Female }(\mathrm{N}=11) \\
13.1 \pm 0.5 \\
(12.2-13.9) \\
\text { Males }(\mathrm{N}=14) \\
12.9 \pm 1.2 \\
(10.0-15.2)\end{array}$ & $\begin{array}{c}\text { Spp. }-F_{1,62}=3.319^{\mathrm{NS}} \\
\text { Sex }-F_{1,62}=4.034^{*} \\
\text { SVL }-F_{1,62}=246.283^{* * *}\end{array}$ \\
\hline HeadW & $\begin{array}{c}\text { Female }(\mathrm{N}=12) \\
9.7 \pm 1.2 \\
(7.6-11.7) \\
\text { Males }(\mathrm{N}=29) \\
9.3 \pm 0.7 \\
(8.0-11.0)\end{array}$ & $\begin{array}{c}\text { Female }(\mathrm{N}=11) \text { : } \\
8.4 \pm 0.5 \\
(7.3-9.0) \\
\text { Males }(\mathrm{N}=14) \\
8.6 \pm 0.9 \\
(7.2-10.3)\end{array}$ & $\begin{array}{c}\text { Spp. }-F_{1,62}=15.288^{* * *} \\
\text { Sex }-F_{1,62}=4.480^{*} \\
\text { SVL }-F_{1,62}=103.616^{* * * *}\end{array}$ \\
\hline HeadH & $\begin{array}{c}6.3 \pm 0.6 \\
(5.1-7.8) \\
N=40\end{array}$ & $\begin{array}{c}6.0 \pm 0.5 \\
(4.5-6.9) \\
N=24\end{array}$ & $\begin{array}{c}\text { Spp. }-F_{1,60}=0.678^{\mathrm{NS}} \\
\text { Sex }-F_{1,60}=0.932^{\mathrm{NS}} \\
\text { SVL }-F_{1,60}=93.771^{* * * *}\end{array}$ \\
\hline NolO & $\begin{array}{c}38 \pm 2 \\
(33-44) \\
N=41\end{array}$ & $\begin{array}{c}37 \pm 2 \\
(33-41)\end{array}$ & $\begin{array}{c}\text { Spp. }-F_{1,63}=3.541^{\mathrm{NS}} \\
\text { Sex }-F_{1,63}=1.439^{\mathrm{NS}} \\
\text { SVL }-F_{1,62}=0.499^{\mathrm{NS}}\end{array}$ \\
\hline NosC & $\begin{array}{c}147 \pm 14 \\
(116-168) \\
N=22\end{array}$ & $\begin{array}{c}163 \pm 42 \\
(115-222) \\
N=20\end{array}$ & $\begin{array}{l}\text { Spp. }-F_{1,39}=3.775^{\mathrm{NS}} \\
\text { Sex }-F_{1,39}=0.004^{\mathrm{NS}} \\
\text { SVL }-F_{1,38}=0.108^{\mathrm{NS}}\end{array}$ \\
\hline OrbL & $\begin{array}{c}3.7 \pm 0.4 \\
(2.6-4.6) \\
N=40\end{array}$ & $\begin{array}{c}3.8 \pm 0.4 \\
(3.0-4.9) \\
N=24\end{array}$ & \\
\hline NarEye & $\begin{array}{c}3.9 \pm 0.4 \\
(3.4-5.1) \\
N=41\end{array}$ & $\begin{array}{c}5.0 \pm 0.4 \\
(3.1-4.5) \\
N=23\end{array}$ & \\
\hline
\end{tabular}




\begin{tabular}{|c|c|c|c|}
\hline Character & $\begin{array}{l}\text { L. stenodactylum } \\
\qquad \mathrm{N}=42\end{array}$ & $\begin{array}{l}\text { L. bungabinna sp. nov. } \\
\qquad \mathrm{N}=25\end{array}$ & Statistics \\
\hline SnEye & $\begin{array}{c}5.4 \pm 0.5 \\
(4.5-6.8) \\
N=41\end{array}$ & $\begin{array}{c}5.0 \pm 0.4 \\
(4.1-5.7) \\
N=24\end{array}$ & \\
\hline EyeEar & $\begin{array}{c}4.7 \pm 0.4 \\
(3.7-6.0) \\
N=41\end{array}$ & $\begin{array}{c}4.5 \pm 0.4 \\
(4.0-5.4) \\
N=24\end{array}$ & \\
\hline INar & $\begin{array}{c}1.6 \pm 0.1 \\
(1.3-1.9) \\
N=41\end{array}$ & $\begin{array}{c}1.6 \pm 0.1 \\
(1.2-1.8) \\
N=23\end{array}$ & \\
\hline 10 & $\begin{array}{c}4.8 \pm 0.4 \\
(4.0-5.8) \\
N=41\end{array}$ & $\begin{array}{c}4.5 \pm 0.3 \\
(3.9-5.1) \\
N=24\end{array}$ & \\
\hline Suplab & $\begin{array}{l}11.0 \pm 1.1 \\
(9-14)\end{array}$ & $\begin{array}{l}11.2 \pm 0.9 \\
(10-13)\end{array}$ & \\
\hline Inflab & $\begin{array}{l}11.7 \pm 1.1 \\
(10-12)\end{array}$ & $\begin{array}{l}12.3 \pm 1.0 \\
(10-14)\end{array}$ & \\
\hline Creasel & $\begin{array}{c}0.39 \pm 0.13 \\
(0-0.75)\end{array}$ & $\begin{array}{c}0.35 \pm 0.31 \\
(0-0.5)\end{array}$ & \\
\hline IntNar & $4 / 42$ & $1 / 24$ & \\
\hline AntSup & $\begin{array}{c}4.4 \pm 0.5 \\
(4-5)\end{array}$ & $\begin{array}{c}4.7 \pm 0.6 \\
(4 \sim 6) \\
N=24\end{array}$ & \\
\hline PostNas & $\begin{array}{c}2.5 \pm 0.6 \\
(2-4)\end{array}$ & $\begin{array}{c}2.5 \pm 0.7 \\
(2-4) \\
N=24\end{array}$ & \\
\hline CS-Large & $\begin{array}{c}1.4 \pm 0.5 \\
(1-3) \\
N=30\end{array}$ & $\begin{array}{c}1.5 \pm 0.5 \\
(1-2) \\
N=14\end{array}$ & \\
\hline CS-Total & $\begin{array}{c}1.7 \pm 0.6 \\
(1-3) \\
N=30\end{array}$ & $\begin{array}{c}1.9 \pm 1.1 \\
(1-5) \\
N=14\end{array}$ & \\
\hline MenL/W & $\begin{array}{c}1.1+0.2 \\
(0.8-1.6)\end{array}$ & $\begin{array}{c}1.2 \pm 0.2 \\
(1.0-1.6)\end{array}$ & \\
\hline TrunkL/SVI & $\begin{array}{c}0.45 \pm 0.03 \\
(0.37-0.53)\end{array}$ & $\begin{array}{c}0.46 \pm 0.03 \\
(0.41-0.51)\end{array}$ & \\
\hline ArmL/SVL & $\begin{array}{c}0.22 \pm 0.01 \\
(0.21-0.24)\end{array}$ & $\begin{array}{c}0.21 \pm 0.01 \\
(0.18-0.24)\end{array}$ & \\
\hline LegL/SVL & $\begin{array}{c}0.30 \pm 0.01 \\
(0.26-0.32) \\
N=41\end{array}$ & $\begin{array}{c}0.28 \pm 0.02 \\
(0.24-0.31) \\
N=24\end{array}$ & \\
\hline Tail\%sVL & $\begin{array}{c}86.8 \pm 5.4 \\
(78.0-103.3) \\
N=22\end{array}$ & $\begin{array}{c}76.1 \pm 9.8 \\
(59.6-95.6) \\
N=21\end{array}$ & \\
\hline HeadL/SVL & $\begin{array}{c}0.26 \pm 0.01 \\
(0.24-0.29) \\
N=41\end{array}$ & $\begin{array}{c}0.26 \pm 0.01 \\
(0.24-0.18)\end{array}$ & \\
\hline HeadW/SVL & $\begin{array}{c}0.18 \pm 0.01 \\
(0.16-0.20) \\
N=41\end{array}$ & $\begin{array}{c}0.17 \pm 0.01 \\
(0.14-0.19)\end{array}$ & \\
\hline HeadH/SVL & $\begin{array}{c}0.12 \pm 0.01 \\
(0.10-0.14) \\
N=40\end{array}$ & $\begin{array}{c}0.12 \pm 0.01 \\
(0.10-0.14) \\
N=21\end{array}$ & \\
\hline
\end{tabular}



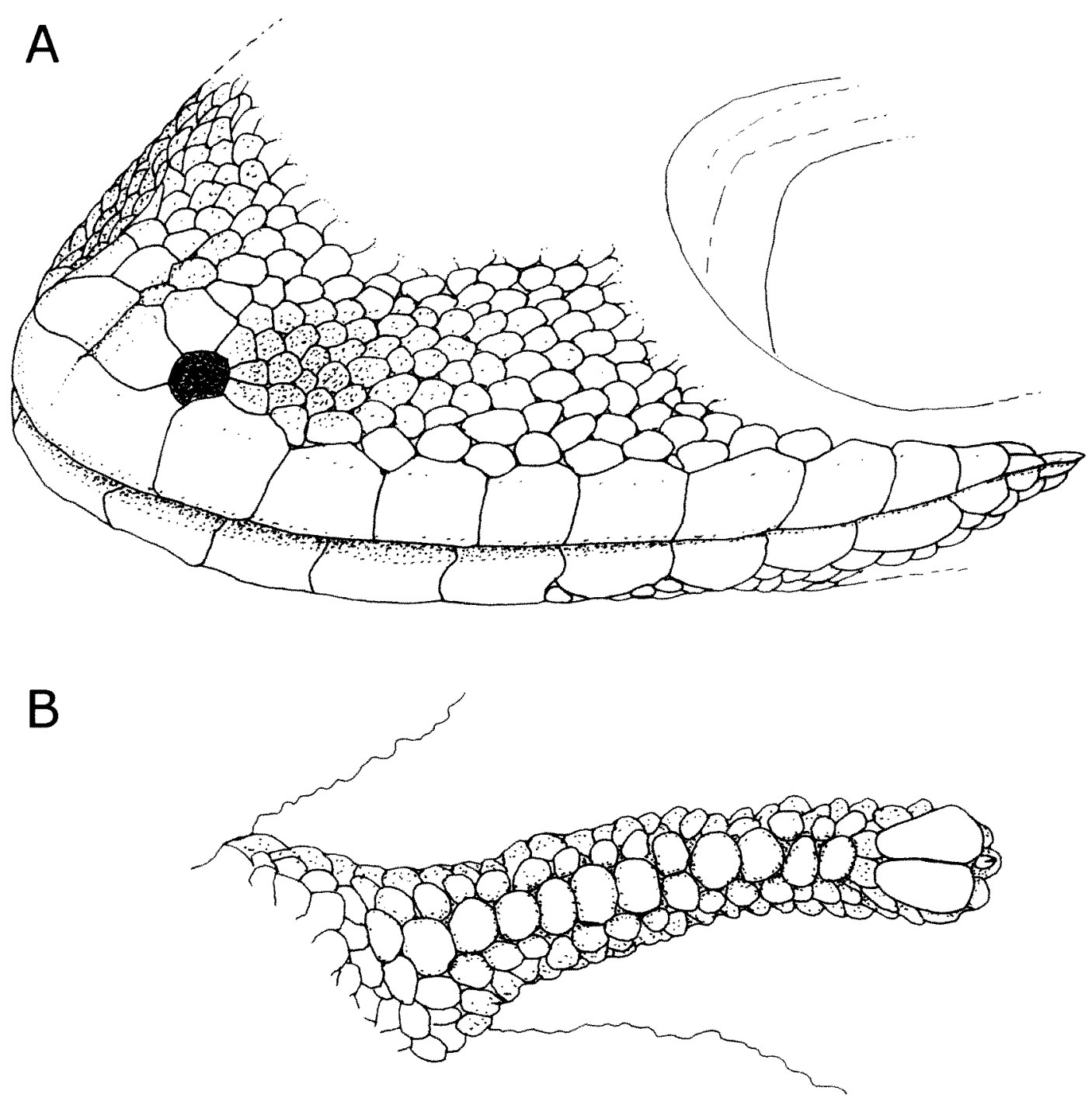

Figure 2 Details of scalation of the snout region and the undersurface of the digits (fourth digit of pes shown) in Lucasium bungabinna sp. nov. (holotype, WAM R166888).

\section{Description}

Table 2 presents a morphological summary. Body and head moderately robust with slender limbs. Tail short to medium length (78-103\% SVL) and slender to moderately thick. Head moderately robust with large eyes. Snout projecting and rounded at tip. Canthus rounded with loreal region moderately shallow (Figure 2A). Labial scales enlarged relative to adjacent scales; 1st supralabial slightly taller than 2 nd. Nostril surrounded by rostral, anterior supranasal, supranasal, 2-3 (occasionally 4) postnasals and first supralabial (Figure $2 \mathrm{~A}$ ). Internasal rarely present and rostral crease averaged about half the height of the scale. Mental scale only slightly longer than wide. Ear opening small and round to D-shaped (rounded side posterior).

Body scales small, slightly rounded and homogeneous. In males, 1-2 (rarely 3 ) large cloacal scales with occasionally smaller scales at the base. All males have 2 preanal pores. Females have enlarged scales where cloacal spurs and preanal pores appear in males, but the 'spurs' do not project and the enlarged scales where the preanal pores are located are not perforated (presumably nonfunctional). Scales on the underside of the postclocal sac greatly enlarged and flat. Scales on tail enlarged towards base of tail and arranged in transverse rows; tip terminating sharply.

Paired subdigital apical plates moderately wide (Figure 2B), total width across pads noticeably greater than width of the digit when viewed dorsally. Claw only moderately long and projecting. Scales on back of digits tend to project towards tips. Subdigital lamellae enlarged relative to adjacent scales (Figure 2B), enlarged rounded scales continue to palmar and plantar surfaces.

\section{Skeleton}

Jugal very small (length of jugal less than half of the distance between the lacrimal foramen and posterior tip of the maxilla) to rudimentary (minute 
A

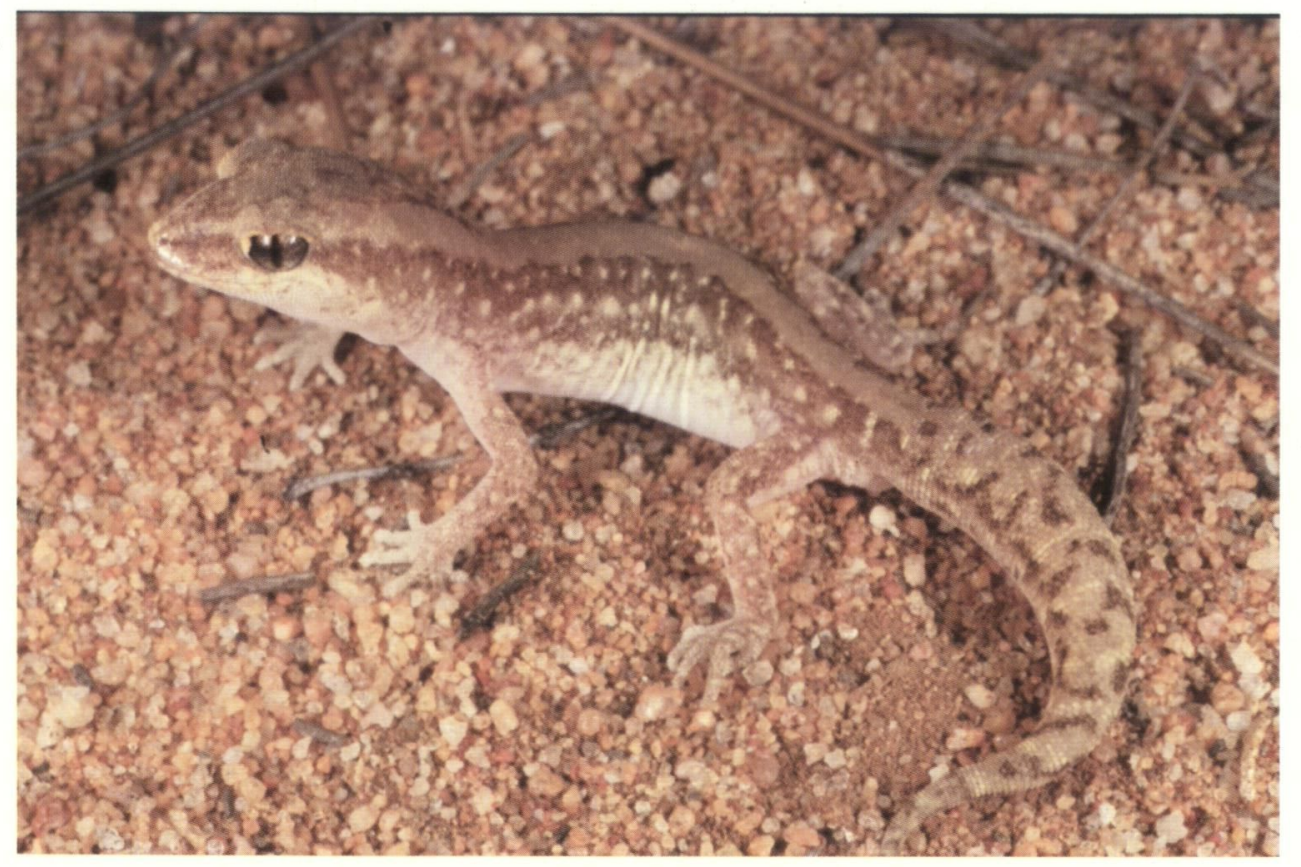

B

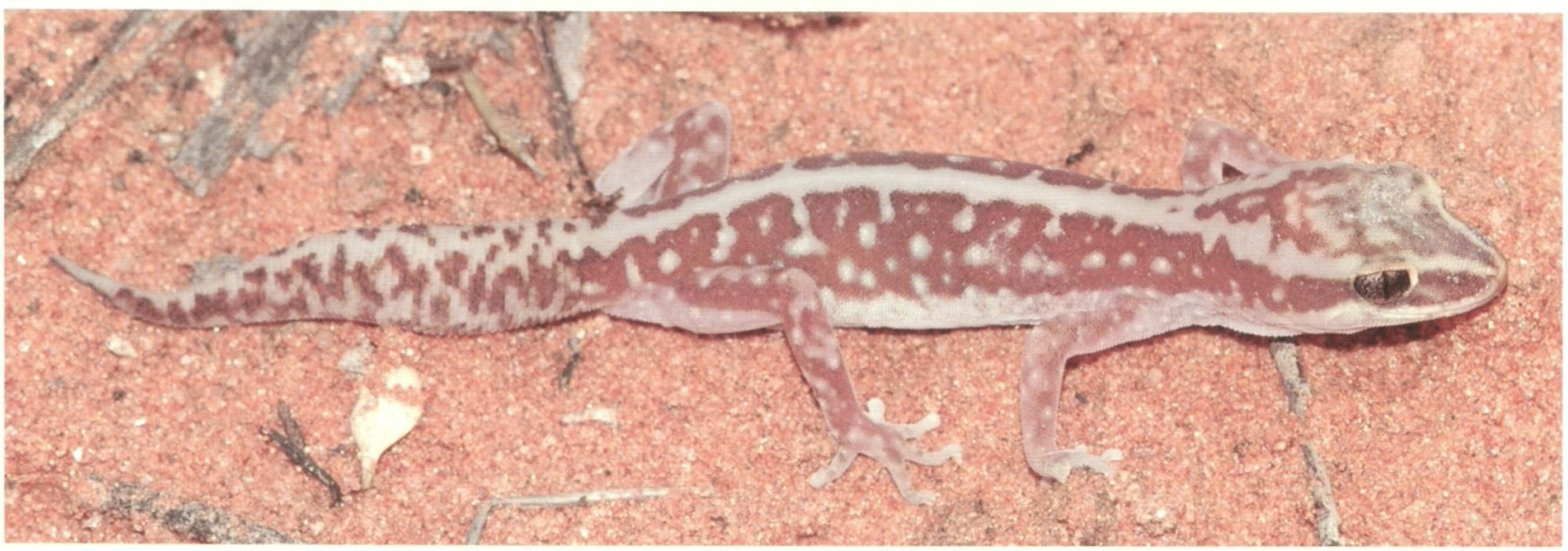

Figure 3 Specimens of Lucasium bungabinna sp. nov. in life. (A) holotype adult male (WAM R166888) from Bungalbin, photo B. Maryan; (B) paratype adult female (SAMA R61197) from the vicinity of Lake Ifould, SA, photo P. Oliver.

ossification lying next to the posterior tip of the maxilla; cf. Oliver et al. 2007, figure 4G). Fourth finger of manus has five phalanges.

\section{Colour}

In preservative, light to medium tan dorsally. Immaculate, straw-coloured vertebral stripe always present, prominent and continuous, with straight or only slightly irregular margins. From base of tail, stripe runs anteriorly to the neck where it bifurcates, continuing as a pale stripe forward to each eye. Outer edge of dorsal stripe sometimes merging with adjacent background colour, but usually narrowly edged by a slightly darker shade of the background colour. Inner margins of the bifurcate region on the nape and occiput often irregular, but always defining an inverted triangle of dorsal background colour. On original tails, margin of the dorsal stripe generally much more irregular and sometimes broken into discontinuous, wavy-edged blotches. Lateral surfaces of body with small pale spots, centred on 3-6 scales but with blurred edges, the light colour graduating to the darker background colour. Often with some larger spots (centres covering 10-15 scales) dorsolaterally, but these also blending with the background colour. Paravertebrally positioned spots sometimes connected to the vertebral stripe via short lines of pale colour. Prominent pale canthal stripe runs from each orbit across the naris to top of the rostral. Limbs somewhat paler in colour than the dorsum and lightly patterned with small pale dots; hind limb often with a darker zone on the trailing edge of the thigh. Ventral surfaces creamy white. 


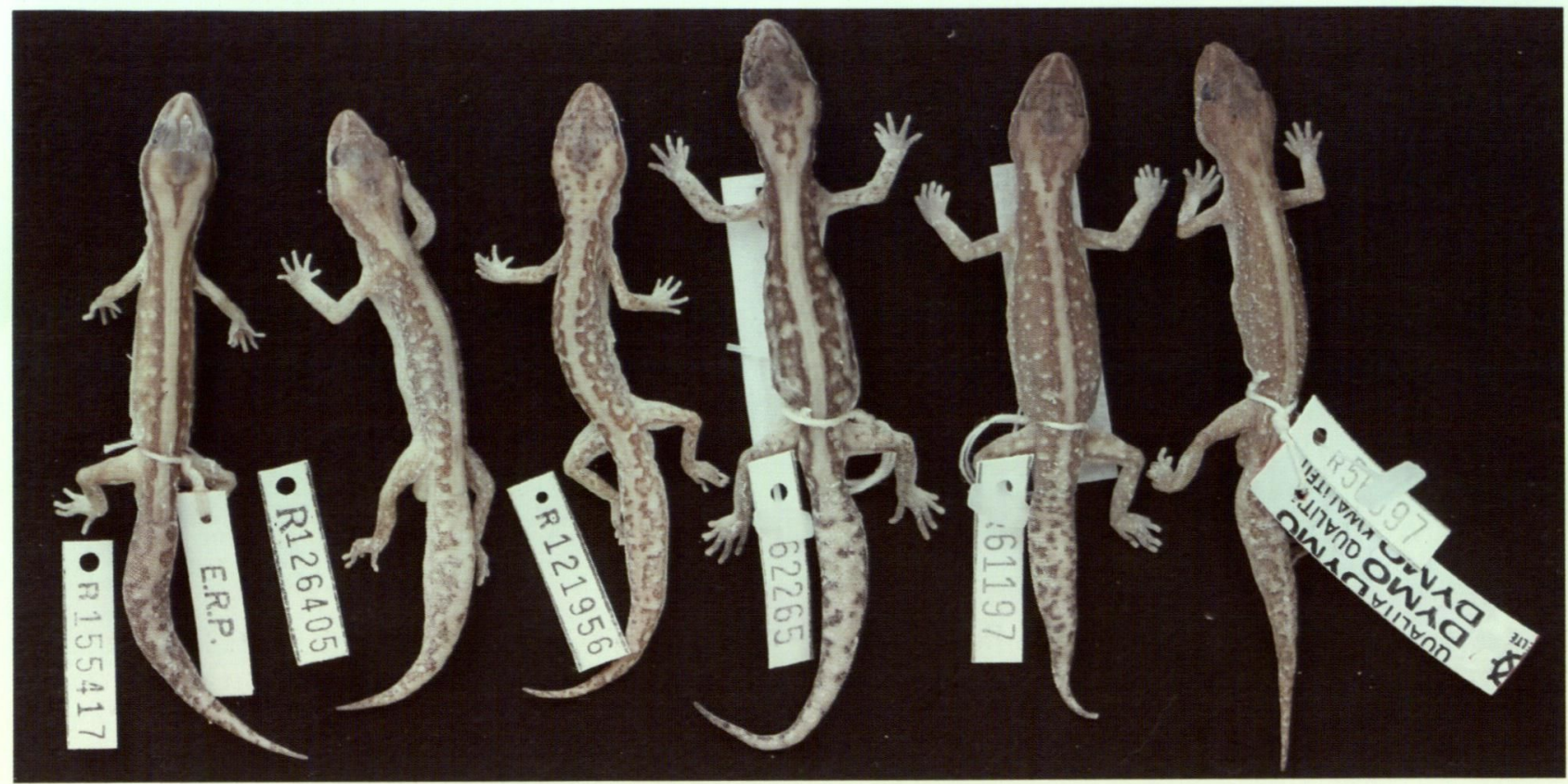

Figure 4 Specimens of Lucasium bungabinna sp. nov. showing the range of variation seen in dorsal pattern. From LR: WAM R155417, WAM R126405, WAM R121956, SAMA R62265, SAMA R61197 and SAMA R56597.

In life, little different from colour in preservative (cf. Figures 3 and 4). Essentially just two dorsal colour tones; a medium sand-brown dorsal colour marked with pale beige dorsal stripe and lateral spots. Underside pure white.

Measurements (mm) and scale counts (holotype): SVL - 41, TrunkL - 16.9, TL - 36, TailW - 4.4, ArmL - 10.1, LegL - 12.7, HeadL - 11.1, HeadW - 7.5, HeadH - 5.7, OrbL - 3.1, NarEye - 3.1, SnEye - 4.3, EyeEar - 3.6, INar - 1.3, IO - 3.8, SupLab - 10, InfLab -10, CreaseL - 1/2, IntNar - 0, AntSup - 4, PostNas - 3, RelLab - 1>2, Cspurs-L - 1, Cspurs-T 2, MenL/W - 1.0.

\section{Distribution}

This species has been found in sandy desert terrain in the southern interior of Western Australia and South Australia. In Western Australia, west to just east of Sandstone $\left(28^{\circ} \mathrm{S} ; 119^{\circ} \mathrm{E}\right)$, south and east through the Yamarna-Lake Yeo area $\left(27.5^{\circ} \mathrm{S} ; 124^{\circ} \mathrm{E}\right)$, then skirting the northern edges of the Nullarbor Plain (ca. 27-28 S) into South Australia. In South Australia, from the Maralinga area $\left(27^{\circ} \mathrm{S} ; 130^{\circ} \mathrm{E}\right)$ southeast to the vicinity of Wirrulla at the top of the Eyre Peninsula $\left(33^{\circ} \mathrm{S} ; 1^{\circ} 5^{\circ} \mathrm{E}\right)$ (Figure 1). Distribution largely occupies the Bungalbin and Yellabinna land systems bordering the southern edge of the Great Victoria Desert.

\section{Variation}

Colour variation shows some local minor individual variation, but relatively little geographic variation (Figure 4 ). In some specimens the dorsal colour is intense only adjacent to the vertebral stripe, and fades laterally so that the flanks are very pale. This results in low contrast between small lateral spots and background colour. Most individuals showing this pattern of variation are from the more westerly parts of the range. A second pattern of variation has the lateral spots tending to coalesce with their neighbours, forming longitudinally or transversely-oriented irregular blotches of lighter colouring. This merging of pale markings also occurs on the legs, forming vague reticulations or longitudinal stripes. Such specimens can occur throughout the species' range, and can resemble some patterns seen in the L. stenodactylum complex. Two specimens from the eastern part of the range (SAMA R56595, R56597; Figure 4) have a very subdued pattern, in which the contrast between the spots, stripes and background colour is low, so that the dorsal stripe contrasts poorly with the adjacent dorsal colour, and the bifurcation on the nape is scarcely visible. This low-contrast variation is similar to that seen in some specimens of $L$. immaculatum. One specimen, WAM R126397 differed in having the rostral excluded from nostril, but in other respects (colour, toe morphology) is typical of $L$. bungabinna.

\section{Comparisons with other species}

Lucasium bungabinna sp. nov. is distinguished from sympatric/parapatric congeners $L$. damaeum Lucas and Frost, 1896, L. maini, L. squarrosum (Kluge, 1962b) and the L. stenodactylum complex by having obvious terminal apical plates (slightly wider than toe tip). In addition, most L. maini and 
$L$. squarrosum and many $L$. damaeum have the vertebral stripe broken into a ragged series of blotches and have a U-shaped area of pale colour on the crown and occiput, narrowly separated from the dorsal pale stripe or blotches. Some populations of the $L$. stenodactylum complex lack an obvious pale vertebral stripe or series of blotches (e.g., many Pilbara specimens). Most $L$. squarrosum are further distinguished by having dorsal body scales larger and more projecting than the lateral and ventral scales, while in many populations assigned to the L. stenodactylum complex the rostral is excluded from the nostril by contact between the anterior supranasal and first supralabial. Distinguished from the allopatric but closely related $L$. immaculatum by rostral in contact with the nostril, pale lateral spots not tending to align transversely and somewhat smaller apical plates. Lucasium bungabinna is distinguished from the remaining species in Lucasium, $L$. alboguttatum, $L$. byrnei (Lucas and Frost, 1896), L. occultum (King, Braithwaite and Wombey, 1982), L. steindachneri (Boulenger, 1885) and L. wombeyi (Storr, 1978), by its colour pattern including a continuous, immaculate vertebral stripe that divides on the nape to end at each eye.

Lucasium bungabinna overlaps geographically with species of the superficially similar Diplodactylus vittatus complex, which have large terminal apical plates and a colour pattern including a strong pale dorsal stripe, but are coloured in buff, grey brown and blackish, have a much shorter, somewhat thickened tail and more numerous postanal spinous scales (5 or more).

\section{Etymology}

The specific epithet has been coined by combining the names of the Bungalbin sandplain (WA) and Yellabinna Dunefield (SA; Copley and Kemper 1992), the land systems from which almost all specimens of $L$. bungabinna have been collected. We treat the name as a noun in apposition.

\section{Remarks}

Lucasium bungabinna is found in sandy desert terrain with a variety of overstorey species, usually mallee (Eucalyptus spp.), but also Allocasuarina, Callitris and (more rarely) Acacia, with equally variable understorey (Triodia, chenopods). It is known to hide by day in holes, including lycosid spider burrows (MNH pers. obs.), and is active entirely at night. Encounters with the species at night indicate that it still climbs to a small extent, specimens having been observed perched in low chenopods (Oliver et al. 2008) and sheltering in spinifex clumps (B. Maryan pers. obs.). Evidently, the relatively enlarged apical plates allow for some climbing abililty not observed in other Lucasium species.
The distribution of $L$. bungabinna suggests a species that has adapted to sandy, low-rainfall areas, but also that some factor prevents its expansion northwards through the Great Victoria Desert proper. The collections of the WA and SA Museums reveal that this distributional pattern is shared with several other reptile species, including Diporiphora linga Houston, 1977, D. reginae Glauert, 1959, Delma petersoni Shea, 1991, Nephrurus stellatus Storr, 1968 and Neelaps bimaculatus (Duméril, Bibron and Duméril, 1854).

Lucasium bungabinna is closely related to $L$. immaculatum (Oliver et al. 2007). The two species are similar in colour and pattern, and in having relatively large apical plates. The two species are widely allopatric, however, separated by approximately $1,000 \mathrm{~km}$ across the Lake Eyre Basin. This region is occupied by at least two major lineages of the $L$. stenodactylum complex (Pepper et al. 2006 and unpublished data), which are evidently able to inhabit broadly similar landforms but occupy areas with distinctly more arid conditions than experienced by either $L$. bungabinna or L. immaculatum.

It is worth noting that in spite of their mostly terrestrial habits, species of Lucasium appear to rely for daytime shelter mainly on the burrows of other organisms (Bustard 1970; Pianka 1989; Storr et al. 1990). Unlike many reptile species that inhabit sandy deserts and make their own burrows, no species of Lucasium has been confirmed as making its own burrow under field conditions. The only likely exception to this is $L$. damaeum, which has completely lost apical plates and is certainly able to burrow actively in sand under captive conditions (MNH pers. obs.), although it also uses ready-made burrows when the opportunity arises (e.g., of the agamid Ctenophorus pictus [Peters, 1866]; Bustard 1970) or in spider burrows, MNH, pers. obs.). Apical plate loss and active burrowing may be related, in that active burrowing would be expected to abrade and damage the delicate surface architecture (Tian et al. 2006) of gecko apical plates. Species such as L. bungabinna and L. immaculatum, as well as other Lucasium with obvious apical plates, like $L$. alboguttatum (Werner, 1919) and $L$. byrnei, would therefore be unlikely to burrow actively and would be expected to be restricted to occupying previously excavated burrows or other retreats. It is tempting to speculate that $L$. bungabinna and L. immaculatum, with their lesser reduction of apical plates and peripheral distributions, represent an early radiation of Lucasium that has been replaced in central Australia by relatives that have become more specialised morphologically and physiologically for life in sandy deserts.

Work in progress by ourselves and colleagues ( $M$. Pepper, J. S. Keogh, P. Oliver) aims to further refine 
our understanding of species boundaries within Lucasium, with the main focus being on populations that remain classified as $L$. stenodactylum.

\section{ACKNOWLEDGEMENTS}

L. A. Smith (WAM) initiated the study by noticing breakdowns in the diagnostic characters across $L$. stenodactylum's range in Western Australia. M. Adams and S. Donnellan (SAMA-EBU) each fortuitously included specimens of $L$. bungabinna in allozyme data sets prepared as parts of other studies; the results they obtained supported the existence of this taxon. We thank M. Pepper, J. S. Keogh and P. Oliver whose molecular studies further supported the genetic distinctiveness of $L$. bungabinna. For the collection of specimens we thank participants of the South Australian Biological Survey, especially D. and G. Armstrong, R. Brandle, P. Canty, J. Foulkes and H. Owens. Helen Owens of the South Australian Dept of Environment and Heritage provided valuable information on habitat associations of specimens collected during survey work. In Western Australia we thank D. Robinson, B. Maryan, C. Dickman and E. R. Pianka. Animals were recently collected under collecting and animal ethics permits issued to the Western Australian Museum by the Department of Environment and Conservation (Western Australia) and to the South Australian Museum by the Department of Environment and Heritage (South Australia). We thank B. Maryan and P. Oliver for the photographs of live specimens, C. Stevenson for generating the map and composite images and $\mathrm{C}$. Bryce for assistance with Figure 4. For comments on previous drafts we thank P. Oliver, B. Maryan and C. Stevenson.

\section{REFERENCES}

Bauer, A.M., Russell, A.P. and Rosenberg, H.I. (1988). Formal taxa, species groups, and perception of the genus Diplodactylus (Reptilia: Gekkonidae). Zoologische Jahrbuch Systematik 27: 44-48.

Boulenger, G.A. (1895). Catalogue of the Lizards in the British Museum (Natural History). British Museum: London, UK.

Boulenger, G.A. (1896). Description of four new lizards from Roebuck Bay, north Western Australia obtained by Dr. Dahl, for the Christiania Museum. Annual Magazine of Natural History 18: 232-235.

Bush, B., Maryan, B., Browne-Cooper, R. and Robinson, D. (2007). Reptiles and Frogs in the Bush: Southwestern Australia. University of Western Australia Press: Crawley, WA.

Bustard, H.R. (1970). Australian Lizards. Collins: Sydney, NSW.

Cogger, H.G. (2000). Reptiles and Amphibians of
Australia (6 $6^{\text {th }}$ edition). Reed New Holland: Sydney, NSW.

Copley, P.B. and Kemper, C.M. (1992). A Biological Survey of the Yellabinna Dunefield, South Australia, in October 1987. South Australian National Parks and Wildlife Service and South Australian Museum, Adelaide (unpublished report).

Donnellan, S.C., Adams, M.A., Hutchinson, M.N. and Baverstock, P.R. (1993). The identification of cryptic species in the Australian herpetofauna: a high research priority (pp. 121-125). In: Lunney, D. and Ayres, D. (eds) Herpetology in Australia: A Diverse Discipline. Surrey Beatty and Sons: Chipping Norton, NSW.

Dumeril, A.M.C., Bibron, G. and Dumeril, A. (1854). Erpetologie Generale ou Historie Naturelle Complete des Reptiles. Roret: Paris, France.

Glauert, L. (1959). A new agamid lizard from Queen Victoria Springs, Western Australia. Proceedings of the Royal Zoological Society of New South Wales 1957-58: 10.

Gray, J.E. (1832). (Three new animals brought from New Holland by Mr. Cuningham.) Proceedings of the Zoological Society of London 1832: 39-40.

Greer, A.E. (1989). The Biology and Evolution of Australian Lizards. Surrey Beatty and Sons: Chipping Norton, NSW.

Günther, A. (1867). Additions to the knowledge of Australian reptiles and fishes. Annual Magazine of Natural History 20: 45-68.

Han, D., Zhou, K. and Bauer, A.M. (2004). Phylogenetic relationships among gekkotan lizards inferred from c-mos nuclear DNA sequences and a new classification of the Gekkota. Biological Journal of the Linnean Society 83: 353-368.

Houston, T.F. (1977). A new species of Diporiphora from South Australia and geographic variation in $D$. winneckei Lucas and Frost (Lacertilia: Agamidae). Transactions of the Royal Society of South Australia 101: 199-206.

King, M., Braithwaite, R.W. and Wombey, J.C. (1982). A new species of Diplodactylus (Reptilia: Gekkonidae) from the Alligator Rivers Region, Northern Territory. Transactions of the Royal Society of South Australia 106: 15-18.

Kluge, A.G. (1962a). A new species of gekkonid lizard, genus Diplodactylus (Gray) from southern interior of Western Australia. Western Australian Naturalist 8: 97-101.

Kluge, A.G. (1962b). A new species of gekkonid lizard, genus Diplodactylus, from the Carnarvon region, Western Australia. Western Australian Naturalist 8: $73-75$.

Kluge, A.G. (1967). Systematics, phylogeny and zoogeography of the lizard genus Diplodactylus Gray (Gekkonidae). Australian Journal of Zoology 15: 1007-1108.

Lucas, A.H.S. and Frost, C. (1896). Reptilia. Report on the Horn Expedition to Central Australia 2: 112-151.

Oliver, P.M., Hutchinson, M.N. and Cooper, S.J.B. (2007). Phylogenetic relationships in the lizard genus Diplodactylus Gray and resurrection of Lucasium 
Wermuth (Gekkota, Diplodactylidae). Australian Journal of Zoology 55: 197-210.

Oliver, P., Hutchinson, M. and Penck, D. (2008). Notes on the biology of an undescribed Lucasium (Gekkonidae). Herpetofauna 37: 90-91.

Pianka, E.R. (1989). The Biology of Desert Lizards. Princeton University Press: Princeton, NJ, USA.

Pepper, M., Doughty, P. and Keogh, J.S. (2006). Molecular systematics and phylogeography of the Australian Diplodactylus stenodactylus (Gekkota: Reptilia) species-group based on mitochondrial and nuclear genes reveals an ancient split between Pilbara and non-Pilbara $D$. stenodactylus. Molecular Phylogenetics and Evolution 41: 539-555.

Peters, W. (1866). Eine Mitteilung uber neue Amphibien (Amphibolorus, Lygosoma, Cyclodus, Masticophis, Crotaphopeltis) und Fische (Diagramma: Hapalogenys) des Kgl. zoologischen museums. Monatsberichte der Königlich Preußischen Akademie der Wissenschaften zu Berlin 1866: 86-96.

Shea, G.M. (1991). Revisionary notes on the genus Delma (Squamata: Pygopodidae) in South Australia and the Northern Territory. Records of the South Australian Museum 25: 71-90.

Storr, G.M. (1968). Nephrurus stellatus, a new knobtailed gecko from southern Australia. Western Australian Naturalist 10: 180-182.
Storr, G.M. (1978). Seven new gekkonid lizards from Western Australia. Records of the Western Australian Museum 6: 337-352.

Storr, G.M. (1988). Three new Diplodactylus (Lacertilia: Gekkonidae) from the arid zone of Australia. Records of the Western Australian Museum 14: 217-223.

Storr, G.M., Smith, L.A. and Johnstone, R.E. (1990). Lizards of Western Australia. IIr. Geckos and Pygopods. Western Australian Museum: Perth, WA.

Tian, Y., Pesika N., Zeng, H.B., Rosenberg, K., Zhao, B.X., McGuiggan, P., Autumn, K. and Israelachvili, J. (2006). Adhesion and friction in gecko toe attachment and detachmient. Proceedings of the National Academy of Sciences of the U.S.A. 103: 19320-19325.

Wermuth, H. (1965). Liste der rezenten Amphibien und Reptilien; Gekkonidae, Pygopodidae, Xantusiidae. Das Tierreich 80: 1-246.

Werner, F. (1910). Reptilia (Geckonidae und Scincidae)(pp. 451-493). In: Michaelsen, W. and Hartmeyer, R. (eds), Die Fauna Sudwest-Australiens. Gustav Fisher: Jena, Germany.

Wilson, S.K. and Swan, G. (2003). A Complete Guide to Reptiles of Australia. Reed New Holland: Sydney, NSW.

Manuscript received 18 April 2008; accepted 22 May 2008. 


\section{APPENDIX}

Specimens examined.

Lucasium bungabinna sp. nov.

WA specimens (WAM): R126393 (M), R126399 (M) and R126407 (M) - Bungalbin Sandplain, $30^{\circ} 17^{\prime} \mathrm{S}, 119^{\circ} 45^{\prime} \mathrm{E}$; R151203 (M) - $20 \mathrm{~km}$ E Sandstone, $27^{\circ} 59^{\prime} \mathrm{S}, 1^{\circ} 9^{\circ} 30^{\prime} \mathrm{E}$; R155402-4 (M), R155407 (F) and WAM R155412 (F) - 7-8 km WNW Point Salvation, $28^{\circ} 14^{\prime} \mathrm{S}, 123^{\circ} 36^{\prime} \mathrm{E}$.

SA Specimens (SAMA): R32162 (F) - $8 \mathrm{~km} \mathrm{SW}$ Maralinga, 30¹2'35"S, 131 $31^{\circ} 15^{\prime \prime} \mathrm{E}$; R56595(M) Ketchalby Rock Hole, 32०39'31"S, 134 59'28"E; R58448(M) - $17.9 \mathrm{~km}$ ENE Wombat Flat, 33⒈'37"S, 13518'37"E; R59369 (M) - 22.5 km NW Maralinga, 30 01'16"S, 131'24'32"E; R61140-1 (M) and R61142 (F) $-8.7 \mathrm{~km}$ ESE Pidinga Tank, Lake Ifould, 3053'14"S, 132 ${ }^{\circ} 12^{\prime} 03^{\prime \prime E}$; R61198 (M) - $6 \mathrm{~km}$ SE Pidinga Tank, Lake Ifould, $30^{\circ} 53^{\prime} 43^{\prime \prime} \mathrm{S}, 132^{\circ} 10^{\prime} 01^{\prime \prime} \mathrm{E}$; R61311 (M) - $8.2 \mathrm{~km}$ NNW Oak Hill, 3208'31"S, 134²0'36"E; R62337 (M) - Anne Beadell Hwy, 47 $\mathrm{km}$ W Vokes Hill corner, 2832'22"S, 13008'53"E.

L. bungabinna examined for skull and mandible characteristics: SAMA R15013, WAM R147384.

\section{Lucasium stenodactylum}

WA specimens (WAM): R108803 (F) - 19 km NE Sandfire, $1^{\circ} 42^{\prime} \mathrm{S}, 121^{\circ} 14^{\prime} \mathrm{E}$; R110591-2 (M) - Tanami Desert, 1953'21"S, 128 51'36"E; R110615 (F) -

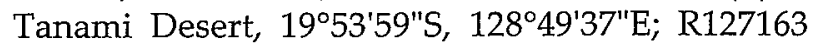
(M) - Nifty Mine, $21^{\circ} 40^{\prime} S, 121^{\circ} 35^{\prime} \mathrm{E} ; \mathrm{R} 145077$ (M) -

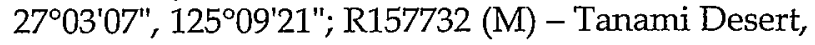
19³4'46"S, 128 52'05"E; R157945 (F) and R157946-7 (M) - Lake Disappointment, $23^{\circ} 17^{\prime} 54^{\prime \prime S}$, $122^{\circ} 42^{\prime} 06^{\prime \prime} \mathrm{E}$; R157948 (F) - Lake Disappointment, 2314'03"S, 122 42'05"E; R157950 (F) - Lake Disappointment, $23^{\circ} 21^{\prime} 07^{\prime \prime S}, 122^{\circ} 40^{\prime} 00^{\prime \prime} \mathrm{E}$.

SA specimens (SAMA): R48940 (M) - $6.4 \mathrm{~km} \mathrm{SE}$ Stonewall Dam, Andamooka Station, 30 44'28"S, $137^{\circ} 20^{\prime} 28^{\prime \prime} \mathrm{E}$; R57910 (F) - $59 \mathrm{~km}$ WNW Emu, $28^{\circ} 32^{\prime} 12^{\prime \prime}$, 131 $36^{\circ} 24^{\prime \prime} E ;$ R58973 (F) - $47.4 \mathrm{~km} \mathrm{~W}$ Oak Valley, 2930'31"S, 130¹5'18"E; R59337 (M) - $41 \mathrm{~km}$ WNW Maralinga, 29 $9^{\circ} 53^{\prime} 47^{\prime \prime S}, 131^{\circ} 16^{\prime} 45^{\prime \prime E}$; R59431 (M) - $61.5 \mathrm{~km} \mathrm{NW}$ Maralinga, $29^{\circ} 48^{\prime} 19^{\prime \prime} \mathrm{S}$, 131'09'21'E; R59482 (M), R59484, (F) - $67.1 \mathrm{~km}$ NNW Maralinga, 29 $43^{\prime} 57^{\prime \prime} \mathrm{S}, 131^{\circ} 05^{\prime} 09^{\prime \prime E}$; R61053

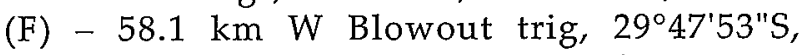
$132^{\circ} 48^{\prime} 44^{\prime \prime}$; R61057 (M) - $50.6 \mathrm{~km} \mathrm{~W}$ Blowout trig,

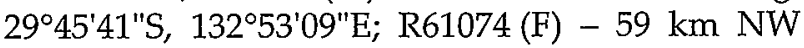
Blowout trig, 2925'09"S, 132 54'30"E; R61097 (M) -

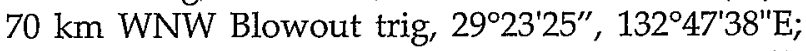
R61775 (F) - $16 \mathrm{~km}$ SW Observatory Hill,

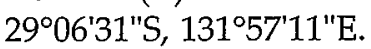

